\title{
Fixed Assets Revaluation and Future Firm Performance: Empirical Evidence from Indonesia
}

\author{
ACHMAD FAIZAL AZMI* \\ Universitas Gadjah Mada \\ SYAIFUL ALI \\ Universitas Gadjah Mada
}

\begin{abstract}
Indonesia's government issued a temporary tax cut law in 2015, which serves as a tax incentive that encourages Indonesian firms to revalue their fixed assets and disclose them in the financial statements according to the assets' fair value. We investigate the association between the revaluation of fixed assets and future firm performance for Indonesian firms. The result shows that the revaluation of fixed assets by Indonesian firms is significantly positively associated with changes in operating income one year after revaluation. Meanwhile, there is no positive association between the revaluation of fixed assets and operating cash flow after two years of revaluation. This result implied that the motivation of revaluation is mainly related to the effort to disclose the fair value of the fixed assets to the user of financial statements. We can conclude that the temporary tax cut law is effective in fostering the future operating performance of the Indonesian firms.
\end{abstract}

Keywords: Fixed assets revaluation, Future firm performance, Indonesia, Temporary tax cut policy.

Abstrak-Pemerintah Indonesia mengeluarkan undang-undang pemotongan pajak yang bersifat sementara pada tahun 2015 yang mana berfungsi sebagai insentif pajak agar mendorong perusahaan Indonesia untuk menilai kembali aset tetap mereka dan mengungkapkannya dalam laporan keuangan sesuai dengan nilai wajar aset tersebut. Penelitian ini bertujuan untuk menemukan bukti empiris mengenai hubungan antara revaluasi aset tetap dan kinerja perusahaan perusahaan Indonesia di masa depan. Hasil penelitian menunjukkan bahwa revaluasi aset tetap oleh perusahaan Indonesia secara signifikan berpengaruh positif terhadap perubahan laba operasi pada satu tahun setelah revaluasi. Sementara itu, tidak ditemukan adanya hubungan positif antara revaluasi aset tetap dan arus kas operasi setelah dua tahun revaluasi. Hasil ini menyiratkan bahwa motivasi utama revaluasi ialah untuk mengungkapkan nilai wajar aset tetap kepada pengguna laporan keuangan. Penelitian ini menyimpulkan bahwa undang-undang pemotongan pajak yang bersifat sementara ini efektif untuk mendorong kinerja operasi perusahaan Indonesia di masa depan. 
Kata Kunci: Revaluasi aset tetap. Performa masa depan perusahaan, Indonesia, Peraturan penurunan tarif pajak yang bersifat sementara,

\section{Introduction}

\subsection{Background}

This paper investigates whether Indonesia's government decision to issue a temporary tax cut policy is effective, to the extent it enhances the future performance of Indonesia's firm. The effectiveness of that policy will be determined by observing the association between revaluations of fixed assets and firms' future performance in Indonesia. One of the emerging issues in Indonesia related to the use of fair value accounting is the revaluation of fixed assets. IFAS 16 has been adjusted to the International Accounting Standard (IAS) 16, which allows companies to value its fixed assets by the revaluation model. However, this revaluation model choice is not mandatory, and it gives flexibility to companies for choosing either the revaluation model or the historical cost model.

In the effort of recovering from the economic slowdown, Indonesia's government issued the temporary tax cut policy for fixed assets revaluation by issuing DMF 191 . This decree temporarily decreases the amount of tax paid by $70 \%$ (3\%) if companies choose to revalue its asset before the end of 2015, 60\% from January 2016 to 30 June 2016 (4\%), and 40\% (6\%) from July 2016 to 31 December 2016. DMF 191 functioned as an incentive for firms to revalue their fixed assets, by minimizing the tax they were obliged to pay. Indonesia's government explicitly stated that the consideration of tax cut policy was targeting macroeconomic stability and enhancing the growth of Indonesia's economy (Kemenkeu, 2015). In other words, specifically for the firm, the government expects that the revaluation of fixed assets could increase their performance and consequently affect Indonesia's economy as a whole.

\subsection{Research Problem and Motivation}

It is known that other researchers have researched an association of fixed assets revaluations and future firm performance. However, there is no definite conclusion 
whether this revaluation of fixed assets can be either positive or negative for a company's performance. Aboody et al. (1999) concluded that revaluation serves a positive effect on future firm performance in the United Kingdom. Moreover, Jaggi and Tsui (2001) also found that upward asset revaluations by Hong Kong firms are significantly positively associated with future firm performance. On the other hand, Zhai (2007) concluded that there is no conclusive evidence that upwards asset revaluations by New Zealand firms are associated with future operating performance, as the associations are not statistically significant. Furthermore, Lopes and Walker (2011) also found out that upward revaluations of fixed assets in Brazil are serving the negative effect on future firm performance, stock prices, and returns.

In terms of Indonesian firms, Kurniawati (2013) found out that there is a difference in share prices before and after of revaluations of a fixed asset by using the Wilcoxon test. However, since there is no regression model used in this research, it cannot be concluded whether there is a significance of the causal relation between the revaluation of fixed assets and future firm performance. Furthermore, this research only uses one subsequent year as a proxy of future performance, which could reduce the validity of the research since the assets that revalued are long-term assets. Thus, the effect of value changes occurs over several years. Zakaria (2015) had attempted to find the motives behind the decision to revalue fixed assets and causality effect of revaluation to future firm performance in Indonesia. However, due to the low level of data on revalued firms available up to 2012, he concluded that the sample size was insufficient to run a robust prediction model for the effects of revaluation decision making to firm future performance.

Most of the prior research related to associations of the revaluation model and future firm performance were conducted in developed countries such as the United Kingdom, New Zealand, and Hong Kong. And then, the answer to whether the revaluation of fixed assets could affect positively or negatively is still debatable. Therefore, providing new insight about the impact of fixed assets revaluations to future firm performance in Indonesia is necessary since it will examine the impact of IFRS adoption, especially related to the revaluation of fixed assets, in terms of an emerging 
country context. Moreover, by knowing the real impact of the revaluation of fixed assets on future firm performance, one can determine the effectiveness of the temporary tax cut policy by Indonesia's government.

\subsection{Research Objective}

This research provides insights into the issue of revaluation of fixed assets in Indonesia since only a few researches have discussed this topic, and previous researchers could not provide sufficient conclusions about the causal effect of the revaluation of fixed assets to firms' future performance in Indonesia. Moreover, more of Indonesia's firms are expected to revalue their fixed assets during this period since there is a temporary tax cut policy for revaluation of fixed assets in 2015. Therefore, a sufficient amount of data could be obtained. This research aims to find the answer to whether Indonesia's government decision to issue a temporary tax cut policy is effective, to the extent it enhances the future performance of Indonesia's firm. Therefore, this research tries to observe the association between revaluations of fixed assets and firms' future performance in Indonesia. The research question is: What is the effect of implementing the fixed assets revaluation model on Indonesian firms' future performance?

\section{Theoretical Framework and Hypothesis Development}

Several factors conceptually bridge the association between the revaluation of fixed assets and future firm performance. This section explains the benefits of fixed assets revaluations from the perspective of fair value in general, reducing debt contracting, which lead to more borrowing capacity, and giving a positive signal about the future performance of the firm. Moreover, previous studies about the association between fixed assets revaluations and future firm performance are also described. The hypotheses will be developed by drawing a preliminary conclusion from the previous research, which relates to the fixed assets revaluation and its effect on future firm performance. 


\subsection{General Advantages of Fair Value}

The revaluation model is established on the principle of fair value accounting. Some studies support the concept of fair value accounting. Landsman (2007) concluded that disclosing fair value is more informative to the investor, but the level of information content depends on the reliability of fair value. By having information about the fair value of assets or liability, the information asymmetry problem between investor and management will be diminished. However, the level of reliability builds upon the accuracy of fair value estimation, especially with the fair value level 3 , which depends on management estimation or external appraisal.

That result is supported by Danbolt and Rees (2008), which stated that the implementation of fair value accounting would generate a consistently more value relevant number than the historical cost. Aboody et al. (1999) concluded that fair value disclosure would produce private information on asset value. This conclusion lined up with Muller et al. (2011), in which using the European firms' investment properties as object research, the result showed that applying fair value for long-lived tangible assets as the mandatory requirement let to the decrease in information asymmetry. This condition represented a significant decline of bid-ask spreads for firms that decide to change from historical cost to fair value.

Fair value accounting not only impacts the way number stated in financial statements, but it also affects the response of management to the economic environment surrounding their business. Managers should understand that they will deal with the system of the open economy, in which market risk will expose the firm. Therefore, they should discover another approach to protect their assets' value (Barlev and Haddad, 2003). Pertaining to the revaluation model, managers will focus on the fair value of their fixed assets. Even though their fixed assets is still in good condition, managers can recognize that the fixed assets become uncompetitive, by looking at the fair value of their fixed assets.

To conclude, fair value is proved to be more beneficial and applicable to the user of financial statements. The usefulness of fair value implementation will result in better financing and/or investing decisions. This conclusion supported by Evans et al. (2014), 
which argued that the ability of unrealized fair value gains and losses component in order to forecast future income and cash flows.

\subsection{Reduced Debt Contracting Cost}

Based on Shivakumar (2013), the majority of the firms utilize debt as its primary source of financing. The rising of almost 95\% capital in the US firms in 2006 was due to the increase of debt (Armstrong et al., 2010). Therefore, debt has a critical role in providing capital for firms. In the positive accounting theory's point of view, firms that are nearly breaking up the debt covenant limit are encouraged to implement accounting methods that enable them to avoid the restriction of debt covenant (Watts and Zimmerman, 1986).

Beneish and press (1995) stated that the financing and investment opportunity of the firms could be limited by the increase of debt covenants to be imposed, which caused by the violation of the debt contract. Some researchers concluded that the implementation of the revaluation model could reduce the debt contracting cost of the firm. Easton et al. (1993) found out that the main reason to apply fixed assets revaluations models is the need to reduce the leverage ratio. The revaluation of fixed assets increases the book value of the total assets. Therefore, it helps the firm's effort for adhering to debt covenant restriction (Brown et al., 1992; Choi et al., 2013). Furthermore, fixed assets revaluation enables the firm to raise its capacity of borrowing by owning more collateral values when having secured debts. The firm can get an advantage from fixed assets revaluation, especially in the time of decreasing cash flow (Cotter and Zimmer, 1995).

Moreover, Whittred and Chan (1992) argued that the implementation of fixed assets revaluations as a method to inhibit undersupply of investment that triggered by the restriction of debt covenant is an inexpensive instrument. As a result, the use of fixed assets revaluation encourages firms to look in the sight of lenders. Therefore, it raises the capacity of borrowing in order to enhance their business operation. 


\subsection{Signaling Better Future Performance}

The information asymmetry is due to unpublished of firms' private information (Conelly et al., 2011). The signaling theory focused on the way to decrease the information asymmetry by providing more signal to the others (Morris, 1987). In regards to the decision of the firm regarding giving more information to others, they would decide the accounting methods that can predict the future cash flow of the firms (Holthausen and Leftwich, 1983; Louis and Robinson, 2005; Badertscher et al., 2012).

Implementation of fixed assets revaluation increases the asset base and the depreciation expense. Therefore, it decreases the current earnings and Returns on Assets (ROA). Those situations have to be compensated for better future performance. Some researchers showed that firms manage to provide a positive signal regarding future performance by executing revaluation of the asset. Jaggi and Tsui (2001) and Chainirun and Narktabtee (2009) concluded that in order to provide a signal regarding the improvement in liquidity and the opportunity to expand business scale, firms decided to perform fixed assets revaluation. Moreover, Lin and Peasnell (2000) and Barlev et al. (2007) argued that firms that have prospective better future performance are deciding to revalue. However, those that anticipate poor future performance are more hesitant to revalue their fixed assets.

\subsection{Prior Research about Impact of Fixed Assets Revaluation}

Several prior studies observed the association between decisions to choose fixed assets to future firm performance. Based on Aboody et al. (1999), in which using UK firm's data from 1983-1995, stated that by measuring the operating income and operating cash flow change for one, two, and there subsequent years, it shows a significant positive relation between fixed assets revaluations and future firm performance. Jaggi and Tsui (2001) that observed Hong Kong firms and applied a similar research design with Aboody et al. (1999) discovered that there is a significant positive relationship between upward fixed assets revaluations and future firm operating income. They concluded that the revaluation of fixed assets emerges from the aim of delivering fair value to the financial statement's user (Jaggi and Tsui, 2001). 
That results are supported by Zhai (2007), which observed New Zealand firms, concluded that the decision to implement a revaluation model for fixed assets has a positive impact on the future operating income, although the relationship is insignificance.

However, contradict most research results in this topic, Lopes and Walker (2012) concluded that fixed assets revaluation shows a negative association on the future firm operating performance, which measured by changes in operating income for one, two, and three subsequent years. This negative effect due to the opportunistic motivation from indebtedness and illiquidity, which also strengthen by the negative association between the Brazilian Corporate Governance Index (BCGI) score and the decision to revalue the fixed assets (Lopes and Walker, 2012).

Overall, most of the previous research found that there is a positive effect of the fixed asset revaluation on the future firm operating income (Aboody et al., 1999; Jaggi and Tsui, 2001; Zhai, 2007). Only Lopes and Walker (2012) argued that there is a negative relationship between the fixed asset revaluation and future firm operating income, which was arguably caused by the revaluers which engaged in opportunistic action and having a low score of BCGI index. However, Siregar and Utama (2008) mentioned that discretionary accruals of Indonesia's firms tend to be for efficient contracting, not for the opportunistic purpose, which implied good corporate governance practice among Indonesia's firms. Furthermore, Wahyudin and Solikhah (2017) argued that the quality of corporate governance perception index (CGPI) of Indonesia's firms are progressing each year positively. Thus, it can be assumed that weak corporate governance is not an issue in this case.

Therefore, by concluding a preliminary finding from prior research regarding the effect of fixed assets revaluation on the future operating income, it can be hypothesized that:

H1: The revaluation of fixed assets is positively associated with the future operating income of Indonesian firms.

In examining the future operating performance of the firm, some previous studies also use operating cash flow as another proxy variable for future operating performance 
(Aboody et al., 1999; Zhai, 2007; Alaadwan and Saaydah, 2015). Furthermore, all previous studies have the same result in which the revaluation of fixed assets positively affects the future operating cash flow of the firms, which measured by one, two, and three subsequent years (Aboody et al., 1999; Zhai, 2007; Alaadwan and Saaydah, 2015). These results supported by Bandyopadhyay et al. (2017) which found that investment property revaluation of Canadian firms is positively related to future cumulative cash flow.

Therefore, by concluding a preliminary finding from prior research regarding the effect of fixed assets revaluations on the future operating cash flow, it can be hypothesized that:

H2: The revaluation of fixed assets is positively associated with the future operating cash flow of Indonesian firms.

\section{Research Method}

\subsection{Data}

Multiple regression analysis is conducted in order to observe the effect of the revaluation of the fixed assets to future firm performance. The research question investigates whether fixed assets revaluation indicates an association with the future performance of Indonesian firms. Indonesian firm means that firms that are listed in the Indonesia Stock Exchange (IDX). This research uses fixed assets revaluation data in the year 2015 because of the temporary tax cut for revaluation of fixed assets was started at that year.

Aboody et al. (1999) stated that revalued fixed assets are classified as long-term assets. Thus, the effect of changes in performance could occur for more than one year. Therefore, this research focused on the operating performance of firms over several years after revaluation happened. However, lack of availability of subsequent data limits the observation to two future years (2016 and 2017). Then, financial institutions will be excluded from the dataset since the composition of its assets are different (Aboody et al., 1999); Jaggi and Tsui, 2001); Zhai, 2007; Lopes and Walker, 2012). 
The amount of upward revaluation was collected from each annual report of the firms, and other variables were collected from the Bloomberg terminal.

The samples of this research are publicly listed firms in the IDX. Only publicly listed firms that have issued the annual report from 2015-2017 that were included in the samples. Also, only the firms which have recognized the net increase in the revaluation of fixed assets in 2015 that were included in the samples. Even though some firms have paid tax for fixed assets revaluation in 2015, however, some of them have not recognized it in the financial statements yet. It happens since the approval of the revaluation of fixed assets by the tax authority occur after the ending of the fiscal year of 2015 .

After having observed publicly listed firms in the IDX, 30 firms have recognized the net increase in the revaluation of fixed assets in 2015. Austin and Steyerberg (2015) concluded that two subjects per variable are enough for creating an accurate estimation of standard error. This research employed five variables for each model, which means 30 samples are more than enough in order to establish valid coefficient regression for the regression analysis.

\subsection{Methodology}

Most of the research in this topic mainly used the panel data analysis, in which it observes the number of firms in a certain time period (Aboody et al., 1999; Jaggi and Tsui, 2001; Zhai, 2007; Lopes and Walker, 2012). However, before the temporary tax cut policy was issued, only a few Indonesian firms chose the revaluation model over the cost model for valuing the fixed assets. Moreover, this research focus only on the year 2015 in order to get one and subsequent two-year performance of the firm. More firms also revalue its fixed assets in the year 2015 (30 firms) since the highest tax cut was provided at that year. Thus, creating a cross-sectional model is still deemed to be appropriate for capturing the effect of the revaluation of fixed assets to the future firm performance on one point in time (one and two subsequent years).

To answer all hypotheses, two separate models were established. STATA statistical software was used for running all models. The proxy for future operating 
performance will be the change in operating income and change in operating cash flow. Barber and Lyon (1996) concluded that that operating income is an appropriate variable for measuring future operating performance since it is a clean measure in which not affected by any special items in the income statement. Moreover, operating cash flow also used as a performance measure since the success of firms mainly related to the ability to generate net cash receipts (Dechow, 1994).

\subsubsection{Operating Performance Test}

The research design for operating performance test focused on whether upward fixed assets revaluation explains the changes in Indonesia's future firm performance. In order to examine the first hypotheses, a model adopted from the previous model of Aboody et al. (1999), Jaggi and Tsui (2001), and Lopes and Walker (2012) were constructed. This model examined how the upward revaluation of fixed assets affecting the future operating income of the firms which revalued their assets:

$$
\begin{aligned}
\Delta \text { OPIN }_{15+\tau, i}= & \alpha+\beta_{1} \text { REV }_{i}+\beta_{2} \text { OPIN }_{i}+\beta_{3} \text { PTB }_{i}+\beta_{4} \text { ASSETS }_{i} \\
& +\beta_{5} \text { REV.D } / E_{i}+\varepsilon_{i} \\
\tau=1,2 &
\end{aligned}
$$

Eq. (1) is separately estimated from changes in operating income over each of the two horizons. $\triangle O P I N_{15+\tau, i}$ is the operating income of firm in $2015+\tau$ minus operating income in 2015. Depreciation and amortization expense will be excluded because asset revaluations affect these amounts (Aboody et al., 1999). Thus, the relation between revaluation and operating income will be diminished. $R E V_{i}$ is the amount of upward revaluation in 2015 as a result of revaluing fixed assets, which become the main explanatory variable for this research. OPIN $i$ is the change in operating income from 2014 to 2015; this variable controls the time-series properties of earnings that can affect future operating income (Aboody et al., 1999). PTB $B_{i t}$ is the price-to-book ratio based on the book value of equity, excluding the amount of upward revaluation, this variable controls for the potential effect of risk and growth on future operating income (Fama 
and French, 1992). ASSETS $i$ is the logarithm of total assets, which excludes the amount of upward revaluation; this variable controls for size effect of the firms (Aboody et al., 1999). REV.D/E $E_{i}$ is the interaction between the amount of revaluation and leverage, which captures the impact of leverage on the relation between the amount of upward revaluation and future firm performance (Lopes and Walker, 2012). In order to make data more comparable among firms, $\triangle O P I N_{15+\tau, i}, R E V_{i}$, and $O P I N_{i}$ were deflated by the market value of equity at the beginning of 2015 (Aboody et al., 1999; Jaggi and Tsui, 2001; Zhai, 2007; Lopes and Walker, 2012).

In examining the second hypothesis, a model adopted from the previous model of Aboody et al. (1999) was constructed:

$$
\begin{aligned}
\Delta C F_{15+\tau, i}= & \beta_{0}+\beta_{1} R E V_{i}+\beta_{2} \Delta C F_{i}+\beta_{3} P_{T B}+\beta_{4} A S S E T S_{i}+\beta_{5} \Delta W C_{i} \\
& +\varepsilon_{i} \quad(2) \\
\tau=1,2 &
\end{aligned}
$$

Eq. (2) is separately estimated from changes in operating cash flow over each of the two horizons. $\triangle C F_{15+\tau, i}$ is operating cash flow of firm in $2015+\tau$ minus operating cash flow in 2015. $\Delta C F_{i}$ is the change in operating cash flow from 2014 to 2015. $\Delta W C_{i}$ is the change in working capital from 2014 to 2015. Lagged working capital was included since Dechow (1994) found out that there is a significant association between operating cash flow and lagged working capital. $\Delta C F_{15+\tau, i}, \Delta C F_{i}$, and $\Delta W C_{i}$ also were deflated by the market value of equity at the beginning of 2015, since the differences in firm size will result in different scales in cash flow from operation (Aboody et al., 1999; Zhai, 2007).

As elaborated above, this research focused on the operating performance of firms over several years after revaluation happened. However, lack of availability of subsequent data limits the observation to two future years (2016 and 2017). Therefore, there were four regression models established in this research, which consist of two regression models for each dependent variable. 


\section{Results and Discussion}

\subsection{Descriptive Statistics}

Table 1.

Descriptive statistics for 30 firms with an upward revaluation of fixed assets in 2015

Variable N Mean Std. Dev. Min Max Median

Dependent Variables

$\begin{array}{lllllll}\Delta \text { OPIN16 } & 30 & 0.0345 & 0.2041 & -0.6399 & 0.3619 & 0.0630 \\ \Delta \text { OPIN17 } & 30 & 0.0782 & 0.3290 & -1.1425 & 0.6481 & 0.1458 \\ \Delta \text { CF16 } & 30 & 0.0225 & 0.5238 & -1.7772 & 1.7912 & 0.0412 \\ \Delta \text { CF17 } & 30 & -0.0309 & 0.4524 & -1.3110 & 1.0642 & 0.0345\end{array}$

Independent Variables

$\begin{array}{lcccccc}\text { REV } & 30 & 0.4278 & 0.6279 & 0.0197 & 2.4513 & 0.1316 \\ \Delta \text { OPIN } & 30 & 0.0029 & 0.1871 & -0.4455 & 0.4554 & -0.0145 \\ \text { PTB } & 30 & 1.3558 & 1.2338 & -0.6400 & 5.3122 & 0.9653 \\ \text { ASSETS } & 30 & 12.4991 & 0.7272 & 10.9686 & 13.658 & 12.5346 \\ \text { REVDE } & 30 & 0.3138 & 0.8525 & -2.6854 & 2.6861 & 0.1026 \\ \Delta \text { CF } & 30 & -0.0672 & 0.5717 & -2.8523 & 0.7824 & -0.0128 \\ \Delta W C & 30 & 6.25645 & 19.5963 & -0.5667 & 102.9509 & 0.1550\end{array}$

Where :

$\triangle O P I N_{15+\tau, i}\left(\Delta C F_{15+\tau, i}\right)$ is the operating income (cash flow) of firm i in year $2015+\tau$ minus operating income (cash flow) in the year 2015. $R E V_{i}$ is the amount of upward revaluation in the year 2015 as a result of revaluing fixed assets. $O P I N_{i}\left(\Delta C F_{i}\right)$ is the change in operating income (cash flow) from the year 2014 to the year 2015. PTB $B_{i t}$ is the price-to-book ratio based on the book value of equity, excluding the amount of upward revaluation. ASSETS $i$ is the logarithm of total assets, which excludes the amount of upward revaluation. $R E V . D / E_{i}$ is the interaction between the amount of revaluation and leverage. $\Delta W C_{i}$ is the change in working capital from the year 2014 to the year 2015. $\triangle O P I N_{15+\tau, i}, R E V_{i}, O P I N_{i}, \Delta C F_{15+\tau, i}, \Delta C F_{i}$, and $\Delta W C_{i}$ will be deflated by the market value of equity at the beginning of the year 2015 .

Table 1 illustrates the descriptive statistics for the dependent and independent variables of this research. It shows that the amount of upward revaluation is quite substantially since the average of the upward revaluation is around $43 \%$ of the market 
value of the equity. As shown in Table 1, the mean of the price-to-book ratio is around 1.3558 , even though the median is only around 0.9653 , which indicates there is a sign of an unrealized asset. Align with the explanation in the introduction of this research, one can argue that revalued firms also suffer from the global economic downturn, in which the average and median of operating income growth in 2015 is only $0.009 \%$ and $-1.45 \%$ of the market value of equity respectively. However, there is an indication of a turnaround in 2016 and 2017, in which the average operating income growth is around $3.45 \%$ and $7.82 \%$ of the market value of equity, respectively. Furthermore, there is an inconsistent sign of the average operating cash flow among revalued firms, in which it arises positively in 2016 by around $2.25 \%$ of the market value of equity. However, it was decreasing by $3.09 \%$ in 2017 .

\subsection{Regression Statistics}

\subsubsection{Regression Statistics for Future Operating Income}

In order to confirm the hypothesis 1 , multiple regression models with changes in operating income in 2016 and 2017 as dependent variables and the amount of upward revaluation as the main independent variable were conducted. However, this research should execute some tests in order to obtain a valid regression result before interpreting the result of regression analysis.

First of all, three observations for the first model and one observation for the second model were deleted from the sample after performing regression statistics and examining the standardized residual for both models. Moreover, the first and second models were re-estimated without the outliers.

After that, in order to determine whether residuals of first and second models were normally distributed or not, this research conducted the Shapiro-Wilk test. As shown in Table 4 and Table 5, the z-value of both models is 0.14575 and 0.17268 . It means that the null hypothesis of normal distribution could not be rejected (significance value of $<0.05$ ), and the residual of both models was normally distributed. Furthermore, by looking at the p-p plot in figure 1, one can argue that the residuals seem to be fitted in the linear line, with only a few slight deviations. 
Furthermore, to examine whether both models could violate the homoscedasticity assumptions, this research employed the Breusch-Pagan test. As shown in Tables 6 and 7 , the chi-square value of both models is 0.4091 and 0.8054 . Since the null hypothesis of this test is that the model has no heteroscedasticity, from the result above, the null hypothesis could not be rejected, and it is concluded that both models were free from heteroscedasticity.

Lastly, in order to examine the existence of multicollinearity within both models, this research conducted a VIF test. As shown in table 8 and table 9, the mean VIF for both models is 1.54 and 1.51. Furthermore, there were no variables that exceed the rule of thumb of tolerable VIF value (10). Therefore, no variables have to be taken out since there was no sign of multicollinearity.

Table 2.

Summary Regression Statistics on Future Operating Income as a Dependent Variable

\begin{tabular}{lccccc}
\hline & & \multicolumn{2}{c}{ One Year Ahead } & \multicolumn{2}{c}{ Two Years Ahead } \\
\cline { 3 - 6 } $\begin{array}{l}\text { Independent } \\
\text { Variable }\end{array}$ & Prediction & Coeff & t-stat & Coeff & t-stat \\
\hline & & & & & \\
REV & + & 0.122 & 2.58 & 0.0465 & 0.57 \\
$\triangle$ OPIN & $?$ & -0.0096 & 0.09 & -0.6100 & 3.17 \\
PTB & $?$ & -0.0118 & 0.51 & -0.0805 & 2.63 \\
ASSETS & $?$ & 0.0520 & 1.69 & -0.0452 & 0.87 \\
REVDE & $?$ & -0.0192 & 0.57 & 0.0233 & 0.41 \\
N & & 27 & & 29 & \\
Adjusted R & & 0.1618 & & 0.3936 & \\
\hline W & & & & &
\end{tabular}

\section{Where :}

$\triangle O P I N_{15+\tau, i}$ is the operating income (cash flow) of firm i in year $2015+\tau$ minus operating income in the year 2015. $R E V_{i}$ is the amount of upward revaluation in the year 2015 as a result of revaluing fixed assets. OPIN $i$ is the change in operating income (cash flow) from the year 2014 to the year 2015. PTB $B_{i t}$ is the price-to-book ratio based on the book value of equity, excluding the amount of upward revaluation. ASSETS $i$ is the logarithm of total assets, which excludes the amount of upward revaluation. $R E V . D / E_{i}$ is the interaction between the amount of revaluation and leverage. $\triangle O P I N_{15+\tau, i}, R E V_{i}$, and $O P I N_{i}$ will be deflated by the market value of equity at the beginning of the year 2015 .

Table 2 exhibits the summary regression statistics from eq (1) regarding the relationship between the upward revaluation of fixed assets and future operating income 
over one and two subsequent years. As shown in Table 2, the REV is statistically significant (5\% significance level) in one year ahead and consistently positive to the future operating income over one and two subsequent years. Interestingly, this result showed that Indonesian firms had obtained the advantage of the fixed asset revaluation in a relatively short-term period (one year). One can argue that the Indonesian government (represented by tax authority) actively provide information to the firm regarding the revaluation of fixed assets from 2015 until 2016. This condition helps the other stakeholders to be aware of the importance of fixed assets revaluations for increasing the performance of the firms. Therefore, it helps the revalued firms for signaling better performance in the future. Furthermore, this positive relationship indicates that the primary reason for the revaluation of fixed assets is disclosing the fair value of fixed assets.

The adjusted R-squared for one- and two-years' time horizons are 0.1618 and 0.3936 , respectively. There is no specific agreement to consider the acceptable level of adjusted R-squared. However, based on the previous research that were conducted by Aboody et al. (1999), Jaggi and Tsui (2001), and Lopes and Walker (2012), the adjusted R-squared ranging from $4 \%$ to $49.2 \%$ and their results are considered good for concluding the explanatory power of revaluation of fixed assets to the future operating income. Therefore, it can be deduced that this regression model still considered to be valid for observing the effect of fixed assets revaluation on the future operating income of the firms.

Pertaining to the control variables, change in the operating income in 2015 is negatively associated with future operating income, and is statistically significant after two subsequent years. This negative association can be indicated as a sign of a turnaround within revalued firms after having negative changes in operating income in 2015. Furthermore, the logarithm of total assets is positively associated with future operating income and statistically insignificant over a two-year horizon. The price-tobook ratio and the interaction term between upward revaluation amount and debt-equity ratio are having an inconsistent association with future operating income over a two- 
year horizon. Therefore, it cannot be concluded whether there is an association between the leverage and revaluation amount to the future operating income.

Overall, consistent with the finding of Aboody et al. (1999) and Jaggi and Tsui (2001), this result shows that disclosing the fair value of fixed assets becomes the primary reason of revaluation of fixed assets, in which can be useful to enhance and forecast the future performance of the firms. Furthermore, it can be concluded that the revaluation of fixed assets is positively associated with future operating income. Therefore, hypothesis 1 is accepted. This result also showed that the temporary tax cut policy issued by the Indonesian government is effective enough for enhancing the future performance of the Indonesian firms in terms of operating income.

\subsubsection{Regression Statistics for Future Operating Cash Flow}

In order to examine hypothesis 2 , multiple regression models with changes in operating cash flow in 2016 and 2017 as dependent variables and the amount of upward revaluation as the main independent variable are executed. However, this research should conduct several tests in order to obtain a valid regression result before interpreting the result of regression analysis.

First of all, one observation from the first model and five observations from the second model were deleted from the sample after performing regression statistics and examining the standardized residual for both models. Moreover, the first and second models were re-estimated without the outliers

After that, in order to determine whether residuals of first and second models were normally distributed or not, this research conducted the Shapiro-Wilk test. As shown in Table 10 and Table 11, the $\mathrm{z}$-value of both models is 0.10887 and 0.67909 . It means that the null hypothesis of normal distribution could not be rejected (significance value of $<0.05$ ), and the residual of both models was normally distributed. Moreover, based on the p-p plot in figure 3 and figure 4, one can argue that the residuals seem to be fitted in the linear line, with only a few slight deviations.

Furthermore, to examine whether both models could violate the homoscedasticity assumptions, this research employed the Breusch-Pagan test. As shown in Table 12 and 
Table 13, the chi-square value of both models is 0.1002 and 0.9862 . Since the null hypothesis of this test was that the model has no heteroscedasticity, from the result above, the null hypothesis could not be rejected, and it is concluded that both models were free from heteroscedasticity.

Lastly, in order to examine the existence of multicollinearity within both models, this research conducted a VIF test. As shown in Table 14 and Table 15, the mean VIF for both models are 1.25 and 1.56. Furthermore, there were no variables that exceed the rule of thumb of tolerable VIF value (10). Therefore, no variables need to be removed since there was no sign of multicollinearity.

Table 3.

Summary Regression Statistics on Future Operating Cash Flow as a Dependent Variable

\begin{tabular}{lccccr}
\hline & & \multicolumn{2}{c}{ One Year Ahead } & \multicolumn{2}{c}{ Two Years Ahead } \\
\cline { 3 - 6 } $\begin{array}{l}\text { Independent } \\
\text { Variable }\end{array}$ & Prediction & Coeff & t-stat & Coeff & t-stat \\
\hline & & & & & \\
REV & + & 0.0288 & 0.34 & -0.0681 & -0.42 \\
$\Delta$ CF & $?$ & -0.0591 & -7.13 & -1.2700 & -6.61 \\
PTB & $?$ & -0.0067 & -0.17 & -0.0183 & -0.58 \\
ASSETS & $?$ & -0.0457 & -0.63 & -0.0170 & -0.22 \\
$\Delta W C$ & $?$ & 0.0003 & 0.11 & 0.0025 & 0.19 \\
$N$ & & 29 & & 25 & \\
Adjusted $R^{2}$ & & 0.6273 & & 0.6384 & \\
\hline Wh & & & &
\end{tabular}

Where :

$\Delta C F_{15+\tau, i}$ is the operating income (cash flow) of firm i in year $2015+\tau$ minus cash flow in the year 2015. $R E V_{i}$ is the amount of upward revaluation in the year 2015 as a result of revaluing fixed assets. OPIN $\left(\triangle C F_{i}\right)$ is the change in cash flow from the year 2014 to the year 2015. PTB $B_{i t}$ is the price-to-book ratio based on the book value of equity, excluding the amount of upward revaluation. ASSETS $S_{i}$ is the logarithm of total assets, which excludes the amount of upward revaluation. $\Delta C F_{15+\tau, i}, R E V_{i}, \Delta C F_{i}$, and $\Delta W C_{i}$ will be deflated by the market value of equity at the beginning of the year 2015 .

Table 3 exhibits the summary of regression statistics from eq (2), which tried to determine the relationship between the upward revaluation of fixed assets and future operating cash flow over one and two subsequent years. The adjusted R-squared for one- and two-years' time horizons are $62.73 \%$ and 63.84 , respectively, which indicate 
good enough explanatory power of the independent variables over the dependent variable. The regression statistics result showed that there is a positive relationship between upward revaluation of fixed assets and future operating cash flow in one subsequent year with a statistical insignificance relationship. However, contrary to the previous studies of Aboody et al. (1999) and Zhai (2007), fixed assets revaluation by Indonesian firms having a statistically insignificance negative association to the future operating cash flow after two subsequent years of revaluation. One can argue that this result caused by the tax imposed by the Indonesian tax authority for every rupiah amount of fixed assets revaluation.

Furthermore, according to the law which governs the temporary tax cut for fixed assets revaluation, the tax rate will return to the initial rate (10\%) in 2017. Since the firms have decided to choose revaluation, they have to do it periodically (as prescribed in IAS 16), thus in case of next upward revaluation of fixed assets, they will bear higher tax payable, assuming the current expectation of no tax rate adjustment in the future. As a result, this will decrease the operating cash flow of the revalued firms, which can be strengthened if the amount of upward revaluation is relatively significant to the amount of equity (like in 2015, which is around $42 \%$ of the market capital). It can be argued that the negative effect of the revaluation of the fixed assets to the operating cash flow of the Indonesian firms is logically right. This negative effect presumably is due to the distinctive national policy, which in this case, is the tax imposed by the Indonesian tax authority.

Regarding the control variable, a change in operating cash flow in 2015 is negatively affected the changes in operating cash flow over one and two subsequent years with a statistically significant relationship. One can argue that this finding explains the recovery of revalued firms after having bad performance in 2015 since the mean of change in operating cash flow in 2015 is negative. The price-to-book ratio and logarithm of total assets are negatively associated with future operating cash flow with an insignificant relationship. Lastly, change in working capital in 2015 is positively associated with the future operating cash flow, despite statistical insignificance over two years horizon. 
Overall, it can be concluded that hypothesis 2 is rejected, the revaluation of the fixed assets does not positively affect the future operating cash flow of the Indonesian firms since the result is inconsistent and statistically insignificant over one and two subsequent years. Specifically, for the negative association that contradicted with others' research, this negative association arguably is due to the inherent attributes of temporary tax cut policy, in which the tax rate will go back to normal after the tax cut period is over.

\section{Conclusion, Implication, and Limitation}

\subsection{Conclusion}

This research investigates whether the temporary tax cut policy for fixed assets revaluation is effective enough to enhance the future performance of the Indonesian firms by testing the relation between fixed assets revaluation with changes in operating income and change in operating cash flow. It is found that fixed assets revaluation by Indonesian firms are significantly positively associated with changes in operating income on one subsequent year after revaluation and insignificantly negatively associated with the change in operating cash flow on two subsequent years after revaluation. These results indicate that the advantage of revaluations of the fixed asset is realized in the following year, and the motivation of revaluation is mainly related to the effort to disclose the fair value of the fixed assets to the user of financial statements.

In contradict with the previous research of Aboody et al. (1999) and Jaggi and Tsui (2001), the finding of this research found that the revaluation of the fixed assets by Indonesian firms is negatively associated with the change in operating cash flow on two subsequent years after revaluation. Even though the relationship is statistically insignificant, it can be argued that this negative effect resulted from the tax obligation to firms for every amount of upward revaluation, which strengthens by the expiration period of temporary tax cut policy at the end of 2016. In case if the firms employed an upward revaluation in 2017 , the firms have to carry a higher tax rate of $10 \%$ compared to 2015 , which only $3 \%$. 
Overall, one can conclude that the temporary tax cut policy of fixed assets revaluation by the Indonesian government can obtain some part of its goal by enhancing the future operating income of the Indonesian firms.

\subsection{Implication and Limitation}

\subsubsection{Practical Implication}

The finding of this research provides several practical implications for the firms and other stakeholders. Firstly, the result of this research can become an encouragement of Indonesian firms to apply the revaluation model. Previously, most Indonesian firms are hesitant to revalue their fixed assets since they have to carry a higher cost, which related to depreciation, tax, and appraisal cost. However, the result of the analysis indicated that the advantage of fixed assets revaluation (enhancing future performance) could exceed the costs that need to be bear by the firms.

Secondly, regarding the government's point of view, the increase in the future performance of the firms will consequently affect the economy positively as a whole, especially related to the rising of tax paid by the firms. However, the Indonesian government should realize that the significantly growing number of firms that adopt the revaluation model should be balanced with the growing number of licensed appraisals. Otherwise, it will take a longer time for the firms to complete the process of fixed assets revaluations. Moreover, based on the findings of future cash flow analysis, the Indonesian tax authority should consider permanently decline the tax rate for the revaluation of fixed assets. Otherwise, the firms with cash flow problems will be hesitant to revalue its fixed assets. This cash flow problem also one of the primary reasons for a low number of firms that implemented the revaluation model (Zakaria, 2015).

\subsubsection{Theoretical Implication}

To the best of author's knowledge, this is the first research that examines the effect of fixed assets revaluation in Indonesia. Therefore, this research sheds light on the impact of fixed assets revaluation to the future performance of the Indonesian firms. 
Moreover, this research provides input to the debate on whether fixed assets revaluation affects positively or negatively to the future performance of the firms. Lastly, by utilizing the data of Indonesian firms, this research also presents new insight into the adoption of IFRS in the emerging country context, especially regarding the fixed assets measurement.

\subsubsection{Limitation}

There are several limitations to this research. First, the application of cross-section regression analysis, which specifically focused on the firms who implemented a revaluation model in 2015, in which due to a time constraint and a low number of revalued firms before 2015. It can be argued that an application of panel data regression analysis will provide stronger evidence in order to capture the effect of the revaluation of fixed assets. Second, this research only considers two subsequent years after revaluation, which differs from any other previous research that covered three subsequent years after revaluation for determining future performance. This limitation ensues because the 2018 fiscal year has not ended yet up until this research was conducted, which made this research only can cover firms' data up until the 2017 fiscal year. Third, the findings reveal that the upward revaluation tax paid by the firms has a probability of affecting the cash flow of the firms, in which the current model has not incorporated it yet. Those limitations can provide further room for improvement to future research. Firstly, in order to obtain stronger evidence related to the effect of fixed assets revaluation on future performance, future research can cover three subsequent years after revaluation.

Moreover, since it is expected that the number of firms that implemented the revaluation model will increase gradually over the year; thus, future research can apply panel data regression analysis in order to get a more accurate inference of parameters in the model. Lastly, future research should incorporate the upward revaluation tax in the model. Therefore, the future finds can confirm whether it is true that the tax paid can result in a negative effect on future firm performance, especially related to the operating cash flow. 


\section{Reference}

Aboody, David, Mary E Barth, and Ron Kasznik. (1999). "Revaluations of fixed assets and future firm performance: Evidence from the UK." Journal of Accounting and Economics 144178.

Aladwan, M. S., \& Saaydah, M. I. (2015). The Relevance of Fair Value Revaluation in the Measurement of Jordanian Firms Future Performance (An Empirical Study on Jordanian Listed Commercial Bank and Real Estate Companies). Jordan Journal of Business Administration, 525-541.

Armstrong, C. S., Guay, W. R., \& Weber, J. P. (2010). The role of information and financial reporting in corporate governance and debt contracting. Journal of Accounting and Economics, 179-234.

Austin, P. C., \& Steyerberg, E. W. (2015). The number of subjects per variable required in linear regression analyses. Journal of Clinical Epidemiology, 627-636.

Badertscher, B. A., Collins, D. W., \& Lys, T. Z. (2012). Discretionary accounting choices and the predictive ability of accruals with respect to future cash flows. Journal of Accounting and Economics, 330-352.

Bandyopadhyay, S. P., Chen, C., \& Wolfe, M. (2017). The predictive ability of investment property fair value adjustment under IFRS and the role of accounting conservatism. Advances in Accounting, 1-14.

Barber, B. M., \& Lyon, J. D. (1996). Detecting abnormal operating performance: The empirical power and specification of test statistics. Journal of Financial Economics, 359399.Barlev, B., \& Haddad, J. R. (2003). Fair Value Accounting and The Management of The Firm. Critical Perspectives on Accounting, 383-415.

Barlev, B., Fried, D., Haddad, J. R., \& Livnat, J. (2007). Reevaluation of Revaluations: A CrossCountry Examination of the Motives and Effects on Future Performance. Journal of Business Finance \& Accounting, 1025-1050.

Barth, M. E., \& Clinch, G. (1998). Revalued Financial Tangible and Intangible Assets: Associations with Share Prices and Non-Market Based Value Estimates. Journal of Accounting Research, 199-233

Beneish, M. D., \& Press, E. (1995). The Resolution of Technical Default. The Accounting Review, 337-353.

Brown, P., Izan, H., \& Loh, A. L. (1992). Fixed Asset Revaluations and Managerial Incentives. ABACUS, 36-57. 
Chairinun, P., \& Narktabtee, K. (2009). The Evidence of Management Motivation to Revalue Property Plant and Equipment in Thailand. NIDA Business Journal, 134-1c55.

Choi, T. H., Pae, J., Park, S., \& Song, Y. (2013). Asset revaluations: motives and choice of items to revalue. Asia-Pacific Journal of Accounting and Economics, 144-171.

Conelly, B. L., Certo, S. T., Ireland, R. D., \& Reutzel, C. R. (2011). Signaling Theory: A Review and Assessment. Journal of Management, 39-67.

Cotter, J., \& Zimmer, I. (1995). Asset Revaluations and Assessment of Borrowing Capacity. ABACUS, 136-151.

Danbolt, J., \& Rees, W. (2008). An Experiment in Fair Value Accounting: UK Investment Vehicles. European Accounting Review, 271-303.

Dechow, P. M. (1994). Accounting earnings and cash flow as measures of firm performance: The role of accounting accruals. Journal of Accounting and Economics, 3-42.

Easton, P. D., Eddey, P. H., \& Harris, T. S. (1993). An Investigation of Revaluations of Tangible Long-Lived Assets. Journal of Accounting Research, 1-38.

Evans, M. E., Hodder, L., \& Hopkins, P. E. (2014). The Predictive Ability of Fair Values for Future financial performance of Commercial Banks and the Relation of predictive Ability to Banks' Share Prices. Contemporary Accounting Research, 13-44.

Fama, E. F., \& French, K. R. (1992). The Cross-Section of Expected Stock Returns. The Journal of Finance, 427-465.

Fitriany, Sidharta Utama, Aria Farahmita, and Viska Anggraita. (2016). "Economic Consequences of IFRS Adoption in Indonesia." American Journal of Economics 79-85.

Hamidah, Iwan Triwuyono, Eko Ganis Sukoharsono, and Ali Djamhuri. (2015). "The Hegemony of International Interest on IFRS Adoption in Indonesia: an Accounting Ecology Perspective." Global Conference on Business and Social Sciences. Bali: Procedia Social and Behavioral Sciences. 104-110.

Holthausen, R. W., \& Leftwich, R. W. (1983). The Economic Consequences of Accounting Choice. Journal of Accounting and Economics, 77-117.

Jaggi, Bikki, and Judy Tsui. (2001). "Management Motivation and Market Assessment: Revaluations of Fixed Assets." Journal of International Financial Management and Accounting 160-187.

Kemenkeu. (2008). PERATURAN MENTERI KEUANGAN TENTANG PENILAIAN KEMBALI AKTIVA TETAP PERUSAHAAN UNTUK TUJUAN PERPAJAKAN. Retrieved from jdih.kemenkeu.go.id: http://www.jdih.kemenkeu.go.id/fullText/2008/79 PMK.03 2008Per.HTM 
Kemenkeu. (2015). "Peraturan Menteri Keuangan Republik Indonesia Nomor 191/PMK.010/2015." $\quad$ www.jdih.kemenkeu.go.id. $\quad$ October 15. http://www.jdih.kemenkeu.go.id/fullText/2015/191 PMK.010 2015Per.pdf.

Kothari, J., \& Barone, E. (2011). Advanced Financial Accounting: An International Approach. Harlow: Prentice-Hall.

Kurniawati, D. (2013). Perbandingan Kinerja Keuangan Perusahaan Sebelum dan Sesudah Revaluasi Aset Tetap di Indonesia (Studi Empiris pada Perusahaan yang Tercatat di Bursa Efek Indonesia 1998-2007) (Bachelor's research). Universitas Gadjah Mada

Landsman, W. R. (2007). Is fair value accounting information relevant and reliable? Evidence from capital market research. Accounting and Business Research, 19-30.

Lin, Y., \& Peasnell, K. (2000). Asset Revaluation and Current Cost Accounting: UK Corporate Disclosure Decisions in 1983. British Accounting Review, 161-187.

Lopes, Alexsandro Broedel, and Martin Walker. (2012). "Asset revaluations, future firm performance, and firm-level corporate governance arrangements: New evidence from Brazil." The British Accounting Review 53-67.

Louis, H., \& Robinson, D. (2005). Do managers credibly use accruals to signal private information? Evidence from the pricing of discretionary accruals around stock splits. Journal of Accounting and Economics, 361-380.

Morris, R. D. (1987). Signaling, Agency Theory and Accounting Policy Choice. Accounting and Business Research, 47-56.

Muller III, K. A., Riedl, E. J., \& Sellhorn, T. (2011). Mandatory Fair Value Accounting and Information Asymmetry: Evidence from the European Real Estate Industry. Management Science, 1138-1153.

Shivakumar, L. (2013). The role of financial reporting in debt contracting and in stewardship. Accounting and Business Research, 362-383.

Siregar, S. V., \& Utama, S. (2008). Type of earnings management and the effect of ownership structure, firm size, and corporate-governance practices: Evidence from Indonesia. The International Journal of Accounting, 1-27.

Watts, R. L., \& Zimmerman, J. L. (1986). Positive Accounting Theory. Englewood Cliffs: Prentice-Hall Inc.

Whittred, G., \& Chan, Y. K. (1992). Asset Revaluations and the Mitigation of Underinvestment. ABACUS, 58-74.

Zakaria, Adam, David John Edwards, Gary David Holt, and Vijay Ramanchadran. (2014). "A Review of Property, Plant, and Equipment Asset Revaluation Decision Making in Indonesia: Development of a Conceptual Model." Mindanao Journal of Science and Technology 109-128. 
The Indonesian Journal of Accounting Research - Sep, Vol. nn, No.n, Year

Zakaria, Adam. (2015). An Empirical Analysis of the Motives for and Effects of Fixed Assets Revaluation of Indonesian Publicly Listed Companies (Doctoral's research). Birmingham City University.

Zhai, Y. (2007). Asset revaluation and future firm operating performance: evidence from New Zealand (Master's research). Lincoln University.

\section{Appendix A:}

Information about the Regression Model with "Operating Income" as Dependent Variable

Table 4.

Result of Shapiro-Wilk Test for One Year Ahead Operating Income as Dependent Variable

\begin{tabular}{|c|c|c|c|c|c|}
\hline Variable & Obs & W & V & Z & Prob>z \\
\hline $\mathrm{r}$ & 27 & 0.94316 & 1.671 & 1.055 & 0.14575 \\
\hline
\end{tabular}

Table 5.

Result of Shapiro-Wilk Test for Two Year Ahead Operating Income as Dependent Variable

\begin{tabular}{|c|c|c|c|c|c|}
\hline Variable & Obs & W & V & Z & Prob>z \\
\hline $\mathrm{r}$ & 29 & 0.94903 & 1.580 & 0.944 & 0.17268 \\
\hline
\end{tabular}

Table 6.

Result of Breusch-Pagan test for One Year Ahead Operating Income as Dependent Variable

\begin{tabular}{|c|c|}
\hline chi2(1) & 0.68 \\
\hline Prob $>$ chi2 & 0.4091 \\
\hline
\end{tabular}

Table 7.

Result of Breusch-Pagan test for Two Year Ahead Operating Income as Dependent Variable

\begin{tabular}{|c|c|}
\hline chi2(1) & 0.06 \\
\hline Prob > chi2 & 0.8054 \\
\hline
\end{tabular}


Table 8.

Result of VIF test for One Year Ahead Operating Income as Dependent Variable

\begin{tabular}{|l|l|l|}
\hline Variable & VIF & $1 /$ VIF \\
\hline REV & 2.16 & 0.463183 \\
\hline$\Delta$ OPIN & 2.00 & 0.499677 \\
\hline PTB & 1.23 & 0.813042 \\
\hline ASSETS & 1.23 & 0.815985 \\
\hline REVDE & 1.08 & 0.922241 \\
\hline Mean VIF & 1.54 & \\
\hline
\end{tabular}

Table 9.

Result of VIF test for Two Year Ahead Operating Income as Dependent Variable

\begin{tabular}{|l|l|l|}
\hline Variable & VIF & $1 /$ VIF \\
\hline REV & 2.16 & 0.463183 \\
\hline$\triangle$ OPIN & 1.08 & 0.499677 \\
\hline PTB & 1.20 & 0.813042 \\
\hline ASSETS & 1.18 & 0.815985 \\
\hline REVDE & 1.95 & 0.922241 \\
\hline Mean VIF & 1.51 & \\
\hline
\end{tabular}

Figure 1.

Normal P-P Plot for One Year Ahead Operating Income as Dependent Variable

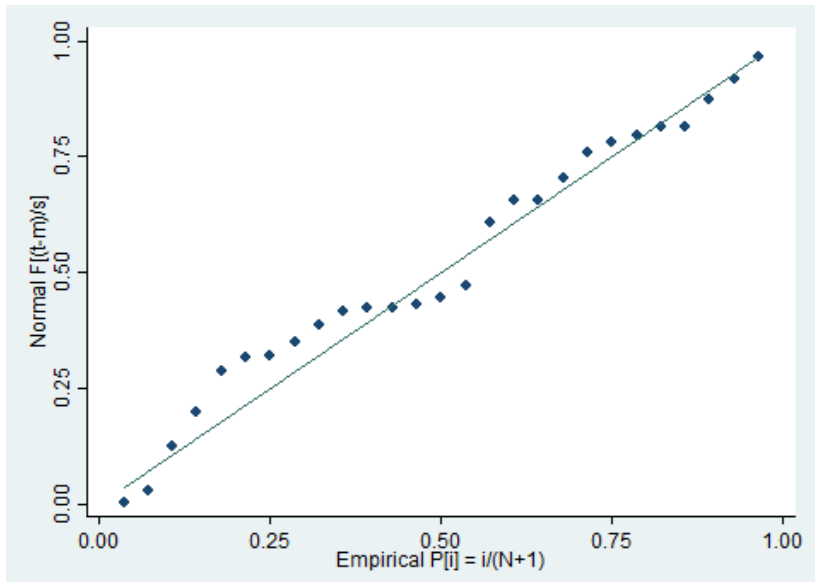


The Indonesian Journal of Accounting Research - Sep, Vol. nn, No.n, Year

Figure 2.

Normal P-P Plot for Two Year Ahead Operating Income as Dependent Variable

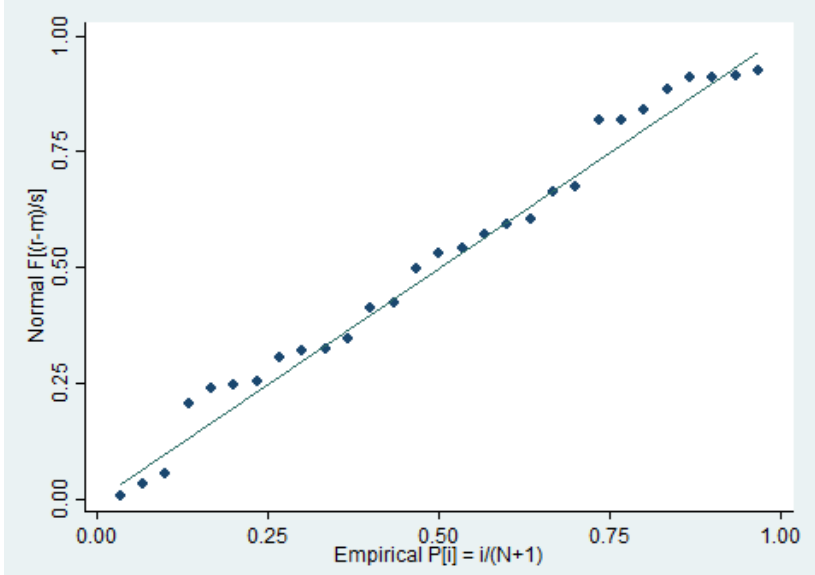




\section{Appendix B:}

Information about the Regression Model with "Operating Cash Flow" as Dependent Variable

Table 10.

Result of Shapiro-Wilk Test for One Year Ahead Operating Cash Flow as Dependent Variable

\begin{tabular}{|c|c|c|c|c|c|}
\hline Variable & Obs & W & V & Z & Prob>z \\
\hline $\mathrm{r}$ & 29 & 0.94316 & 1.817 & 1.233 & 0.10887 \\
\hline
\end{tabular}

Table 11.

Result of Shapiro-Wilk Test for Two Year Ahead Operating Cash Flow as Dependent Variable

\begin{tabular}{|c|c|c|c|c|c|}
\hline Variable & Obs & W & V & Z & Prob>z \\
\hline$R$ & 25 & 0.97134 & 0.796 & -0.465 & 0.67909 \\
\hline
\end{tabular}

Table 12.

Result of Breusch-Pagan test for One Year Ahead Operating Cash Flow as Dependent Variable

\begin{tabular}{|c|c|}
\hline chi2(1) & 2.70 \\
\hline Prob $>$ chi2 & 0.1002 \\
\hline
\end{tabular}

Table 13.

Result of Breusch-Pagan test for Two Year Ahead Operating Cash Flow as Dependent Variable

\begin{tabular}{|c|c|}
\hline chi2(1) & 0.00 \\
\hline Prob > chi2 & 0.9862 \\
\hline
\end{tabular}

Table 14.

Result of VIF test for One Year Ahead Operating Cash Flow as Dependent Variable

\begin{tabular}{|l|l|l|}
\hline Variable & VIF & $1 /$ VIF \\
\hline REV & 1.53 & 0.654556 \\
\hline$\Delta$ OPIN & 1.30 & 0.768877 \\
\hline PTB & 1.29 & 0.775143 \\
\hline ASSETS & 1.09 & 0.920707 \\
\hline REVDE & 1.06 & 0.942724 \\
\hline Mean VIF & 1.25 & \\
\hline
\end{tabular}


The Indonesian Journal of Accounting Research - Sep, Vol. nn, No.n, Year

Table 15.

Result of VIF test for Two Year Ahead Operating Cash Flow as Dependent Variable

\begin{tabular}{|l|l|l|}
\hline Variable & VIF & $1 /$ VIF \\
\hline REV & 1.92 & 0.520222 \\
\hline$\Delta$ OPIN & 1.84 & 0.543326 \\
\hline PTB & 1.66 & 0.603690 \\
\hline ASSETS & 1.26 & 0.790764 \\
\hline REVDE & 1.10 & 0.906869 \\
\hline Mean VIF & 1.56 & \\
\hline
\end{tabular}

Figure 3.

Normal P-P Plot for One Year Ahead Operating Cash Flow as Dependent Variable

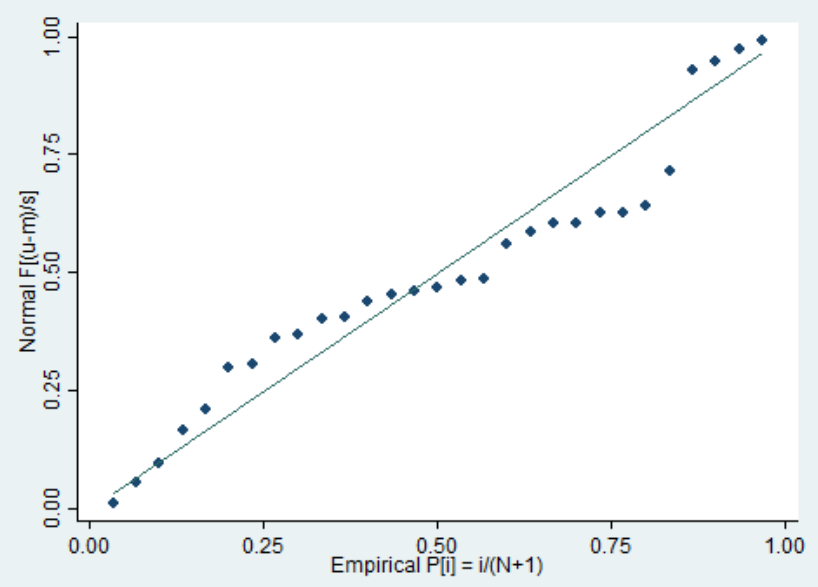

Figure 4.

Normal P-P Plot for One Year Ahead Operating Cash Flow as Dependent Variable

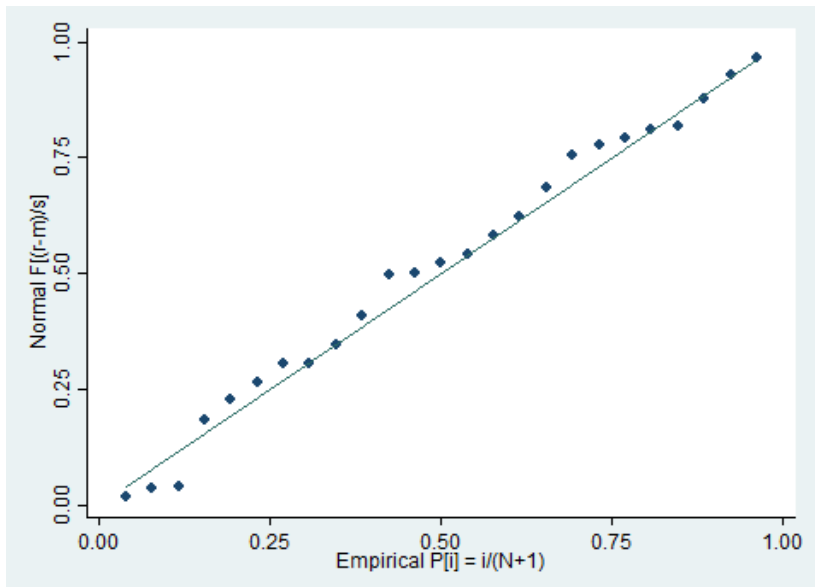

